\title{
Selective modulation of ANP-dependent dilatation in the pulmonary vasculature by PDE 5 inhibitors: a novel combination therapy for pulmonary hypertension?
}

\author{
Reshma S Baliga*1,2, Lan Zhao ${ }^{3}$, Martin R Wilkins ${ }^{3}$, Raymond J MacAllister ${ }^{1}$ \\ and Adrian J Hobbs ${ }^{2}$
}

\begin{abstract}
Address: ${ }^{1}$ Department of medicine, Centre for Clinical Pharmacology, University College London, London, UK, WC1 6JJ, UK, ${ }^{2}$ Wolfson Institute for Biomedical Research, University College London, Cruciform Building, Gower Street, London, WC1E 6AE, UK and ${ }^{3}$ Section on Clinical Pharmacology, Faculty of Medicine, Imperial College London, Hammersmith Hospital, London, UK

Email: Reshma S Baliga* - r.baliga@ucl.ac.uk

* Corresponding author
\end{abstract}

from $3^{\text {rd }}$ International Conference on cGMP Generators, Effectors and Therapeutic Implications

Dresden, Germany. 15-17 June 2007

Published: 25 July 2007

BMC Pharmacology 2007, 7(Supp| I):P2 doi:I0.I |86/I47|-22 I0-7-SI-P2

This abstract is available from: http://www.biomedcentral.com//47I-22I0/7/SI/P2

(c) 2007 Baliga et al; licensee BioMed Central Ltd.

\section{Background}

Pulmonary hypertension has a high mortality, in part because of the paucity of selective pulmonary vasodilators. We have demonstrated previously that the phosphodiesterase (PDE) 5 inhibitor sildenafil augments dilatation to atrial natriuretic peptide (ANP) in the pulmonary, but not systemic, vasculature. This supports the hypothesis that cGMP-mediated vasodilatation by ANP is regulated by PDE V specifically in the pulmonary vascular bed, and that modulation of the natriuretic peptide system could be beneficial in the treatment of pulmonary hypertension.

\section{Materials and methods}

Male Sprague Dawley rats were divided into groups, pretreated with either ecadotril (neutral endopeptidase [NEP]inhibitor; prevents natriuretic peptide hydrolysis) $60 \mathrm{mg} / \mathrm{kg} /$ day by gavage, sildenafil $30 \mathrm{mg} / \mathrm{kg} /$ day in the drinking water, or a combination of both, and subjected to 2 weeks of hypoxia ( $10 \%$ oxygen) to induce pulmonary hypertension. Hypoxic and normoxic controls were also included. After two weeks, pulmonary, right ventricular and systemic pressures were determined by fluid filled catheterisation in anaesthetised animals. Animals were then euthanised and hearts and lungs excised for further analysis.

\section{Results}

In untreated control rats, 2 weeks of $10 \%$ hypoxia produced markedly elevated mean pulmonary pressures $(28.9 \pm 2.2 \mathrm{mmHg})$ as compared to normoxia controls $(18.44 \pm 1.9 \mathrm{mmHg} ; P<0.05)$. Both sildenafil treated $(24.07 \pm 0.5 \mathrm{mmHg})$ and ecadotril treated $(25.45 \pm 1.4$ $\mathrm{mmHg}$ ) animals showed a statistically significant reduction in PAP with a further reduction $(21.27 \pm 1.4 \mathrm{mmHg})$ observed in the combined treatment group. Similarly, 2 weeks of hypoxia produced a doubling of the right ventricular systolic pressure (RVSP) in untreated hypoxic rats $(41.2 \pm 2.0 \mathrm{mmHg})$ as compared to normoxia controls $(26.8 \pm 6.6 \mathrm{mmHg} ; P<0.05)$. Treatment with sildenafil $(40.2 \pm 4.5 \mathrm{mmHg})$ or ecadotril $(41.3 \pm 4.5 \mathrm{mmHg})$ alone failed to reduce RVSP, but the sildenafil + ecadotril group showed reduced RVSP $(35.3 \pm 1.8 \mathrm{mmHg} ; P<0.05)$. Systemic blood pressure was not changed in any of the groups. In accord with the changes in pulmonary haemodynamics, the right ventricular hypertrophy (right to left ventricle weight ratio) and vascular remodelling in the lung ( $\%$ of muscularised vessels) following hypoxia were reduced with each of the treatment regimes.

\section{Conclusion}

These data suggest that a combination of sildenafil and ecadotril has a synergistic effect to lower pulmonary arte- 
rial pressure in pulmonary hypertension. However, there is no effect of this combination on systemic blood pressure, so the presence of NEP blockade appears to increases the pulmonary selectivity of sildenafil, and this combination treatment might be of therapeutic benefit in treating pulmonary hypertension.

Publish with Bio Med Central and every scientist can read your work free of charge

"BioMed Central will be the most significant development for disseminating the results of biomedical research in our lifetime. " Sir Paul Nurse, Cancer Research UK

Your research papers will be:

- available free of charge to the entire biomedical community

- peer reviewed and published immediately upon acceptance

- cited in PubMed and archived on PubMed Central

- yours - you keep the copyright

Submit your manuscript here:

http://www.biomedcentral.com/info/publishing_adv.asp 